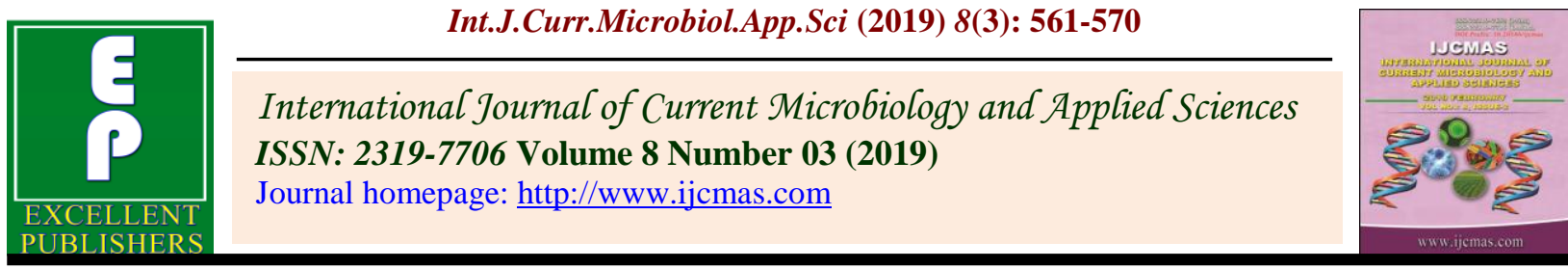

\title{
A Comparative Study on Nutritional Profile and Antinutrients of Buckwheat Fractions (Fagopyrum esculentum)
}

\author{
Mani Mishra* and Shashi Jain \\ Maharana Pratap University of Agriculture and Technology Udaipur, Rajasthan, India \\ *Corresponding author
}

Keywords

Antinutrients,

Phytic acid,

Proximate

composition

Article Info

Accepted:

07 February 2019

Available Online:

10 March 2019

\section{A B S T R A C T}

Buckwheat (Fagopyrum esculentum) is an annual crop, it is a pseudo cereal but its grains belong to cereals because of their similar use and chemical composition. Buckwheat grains and other tissues contain numerous neutraceutical compounds. A Comparative study on Nutritional profile and Antinutrients of buckwheat fractions was conducted at Department of Food \& Nutrition, College of Home Science, Maharana Pratap University of Agriculture \& Technology Udaipur, Rajasthan, India. The chemical analysis of buckwheat fractions buckwheat whole (BW), buckwheat groats (BG) and buckwheat husk (BH )for proximate composition revealed significant difference for moisture, fat, ash, protein, fibre and energy. Protein was significantly higher in BG $(14.88 \mathrm{~g} / 100 \mathrm{~g})$ than BW $(11.34 \mathrm{~g} / 100 \mathrm{~g})$ and $\mathrm{BH}(9.91 \mathrm{~g} / 100 \mathrm{~g})$. It was observed that all three fractions of buckwheat exhibited almost similar values of carbohydrate content which ranged from $66.35 \mathrm{~g} / 100 \mathrm{~g}$ in $\mathrm{BW}$ to $71.25 \mathrm{~g} / 100 \mathrm{~g}$ in $\mathrm{BH}$. The significant difference was found between fractions for calcium, Iron, and Zinc. In case of calcium, BH recorded higher value $149.66 \mathrm{ppm}$ than BW and BG (76.80 ppm and $38.13 \mathrm{ppm})$. The anti-nutritional factors viz., tannin and phytic acid were analyzed in all flour fractions. Tannin content was found to be highest in BH (5.54\%) than BW (4.15\%) and BG (4.15\%). The phytic acid content was found lowest in BG $(6.23 \%)$ than BW (18.36\%) and BH (18.30\%) and the difference was significant ( $\mathrm{p} \geq 0.05)$.

\section{Introduction}

Buckwheat is produced in many parts of the world and has long been an important part of the human diet. Buckwheat has a triangular seed, which is covered by a hull (pericarp). The exact shape, size, and colour of the seed may vary depending on the species and variety. The hull may be a glossy or dull brown, black or grey. The dehulled buckwheat seed, called the groat, resembles the cereal kernel in its gross chemical composition and structure. The first layer of the groat is aonecell thick testa layer (seed coat), which is light green in colour. Under the testa is a one-cell aleurone layer, which surrounds the starchy endosperm. The inner portion of groat consists of a spermaderm and an endosperm. Later, it was suggested by Krtov (1963) that buckwheat originated in temperate central Asia from where it has migrated to other countries of the region. The perennial wild species Fagopyrum cymosum, native to China and India was considered to 
be the progenitor of the two commonly cultivated species, Fagopyrum esculentum (Common buckwheat) and $F$. tataricum (Tatary buckwheat). Hindi name for buckwheat (Fagopyrum esculentum) is "Kutu" and it's an ancient crop of India cultivated extensively in the Himalayan region extending from Jammu and Kashmir in the north-west to Arunachal Pradesh in the north eastern region. Buckwheat has gained an excellent reputation for its nutritious qualities in the human diet.Its renewed popularity stems from its many bioactive components, which have been shown top rovide various health benefits much sought after in natural foods. Buckwheat flour contains various kinds of vitamins, such as B1, B2, and niacin, at relatively high levels (Pomeranz, 1983). Buckwheat protein consists of $18.2 \%$ albumin, $43.3 \%$ globulin, $0.8 \%$ prolamin, $22.7 \%$ glutelin, and $5.0 \%$ other nitrogen residue (Javornikand Kreft, 1984).

Buckwheat contains many flavonoid compounds, known for their effectiveness in reducing the blood cholesterol, keeping capillaries and arteries strong and flexible, and assisting in prevention of high blood pressure (Santos et al, 1999). Buckwheat proteins, like dietary fibre, can suppress the development of colon cancer (Lipkin et al., 1999). The content of TDF in groats may range from 5 to $11 \%$. Bran fractions obtained by milling of buckwheat are especially enriched in dietary fibre (13-16\%), but buckwheat flours contain considerably lower amounts of fibre (1.7-8.5\%) (Steadman et al., 2001).

Buckwheat flour can be avaluable ingredient in diets or food products for celiac patients. It is observed that Buckwheat is a nutritious food having therapeutic role in diseases like Diabetes, hypertension, cancer, constipation and celiac disease. It is a good source of protein, vitamins, and minerals bioactive components like flavonoids makes it a boon for health.

\section{Materials and Methods}

The present study was conducted at Department of Food \& Nutrition, College of Home science, Maharana Pratap University of Agriculture \& Technology Udaipur, (Rajasthan).Buckwheat sample as whole (BW) and Buckwheat groats (BG) purchased from local market of Udaipur (Rajasthan) in a single lot to avoid varietal difference. The samples are shown in plate 1.Sample was stored in airtight container Buckwheat whole (BW) cleaned separately by sieving for removal of dirt, stones and stored in airtight container. ZanduParad Tablets (covering with a piece of cotton cloth) added (2 tablets for 1 $\mathrm{kg}$ seed). Every 2-3 months interval samples were spread in sunlight and again stored.

Nutritional components: Buckwheat whole (BW), Buckwheat groats (BG) and buckwheat husk $(\mathrm{BH})$ were analyzed for nutritional content along with buckwheat whole and buckwheat groats. Buckwheat husk was also analyzed as most trace elements are concentrated in bran (Bonafaccia et al., 2003). Buckwheat husk (BH) was obtained by grinding buckwheat whole in a grinder for 2-3 minutes and husk removed manually by hand. About 50-60 percent part of buckwheat was separated as buckwheat husk (BH).

Nutritional evaluation of the buckwheat whole (BW) was done for their proximate composition and mineral estimation (calcium, iron, zinc, copper). Anti-nutritional factors (tannins and phytates) were also analyzed. Standard procedures were used for the estimations. Percentage carbohydrate and energy contents were determined by calculation using difference method respectively. The procedures have been described here under: 


\section{Proximate composition}

It is the determination of a group of closely related compounds together. It includes determination of amount of moisture, protein, fat (ether extract), ash and fiber with nitrogen free extract and carbohydrates being estimated by subtracting the sum of these five percentages from 100.

\section{Moisture}

It is the major component of food. The moisture content of any food is determined not only to analyze the chemical composition of food material on moisture free basis but also to assess the shelf life of the products. Moisture content of samples was analyzed by the method described by NIN (1983).Ten gram sample was weighed in a dried and weighed petri dish. The weight of the sample along with the petri dish was taken at regular intervals until a constant weight was obtained. The moisture percentage was calculated using following formula:

$$
\begin{aligned}
& \text { Initial weight }(\mathrm{g}) \text { - Final weight }(\mathrm{g}) \\
& \text { Moisture }(\mathrm{g} / 100 \mathrm{~g})=\frac{\mathrm{X}}{\text { Weight of the sample }(\mathrm{g})}
\end{aligned}
$$

\section{Crude protein}

The protein nitrogen is converted into ammonium sulphate by boiling with concentrated sulphuric acid. It is subsequently decomposed by the addition of excess alkali and the liberated ammonia is absorbed into boric acid solution containing an indicator by steam distillation. Ammonia forms a loose compound, ammonium borate with boric acid, which is titrated directly against standard $\mathrm{HCl}$. The protein content of food stuff is obtained by estimating the nitrogen content of the material and multiplying the nitrogen content by the factor 6.25 (NIN, 1983).
Kjel plus nitrogen estimation system was used to estimate the amount of nitrogen in the samples. $0.2 \mathrm{~g}$ moisture free sample was transferred to the digestion tube. Ten $\mathrm{ml}$ of concentrated sulphuric acid and $3 \mathrm{~g}$ catalyst mixture (5 parts of $\mathrm{K} 2 \mathrm{SO} 4+1$ part of $\mathrm{CuSO} 4)$ was added and was left overnight. The tubes were then placed in a pre-heated digestion block. The digestion block was pre heated to $60^{\circ} \mathrm{C}$ for 10 minutes. Once the digestion tubes were placed, temperature was further increased to $100^{\circ} \mathrm{C}$ and samples were kept until the colour of the samples turned bluish green or colorless. Digested samples were taken for distillation where the ammonium radicals were converted to ammonia under excess alkali post neutralization of acid in the digested samples with 40 per cent sodium hydroxide. Mixed indicator (methyl red + methyl blue) was added to the solution and titrated with the standardized $\mathrm{N} / 10 \mathrm{HCl}$. The titration value was determined and the following formula was used to estimate the amount of nitrogen liberated:

14.01xNormality of HCL (0.1) x (TV-BV Nitrogen $(\mathrm{g} / 100 \mathrm{~g})=\frac{\mathrm{SW}(\mathrm{gm})}{\mathrm{X} 100}$

\section{Crude fat}

Fat was estimated as crude ether extract of moisture free sample by the method given by Jain and Mogra (2006). Fat content of the sample was estimated on Soxhlet Plus system, which works on the principle of improved soxhlet method. Weighed amount of moisture free sample (5 g) was placed in a thimble. The thimble was inserted in the thimble holder to be kept in an already weighed beaker and 80 $\mathrm{ml}$ petroleum ether $\left(60-80^{\circ} \mathrm{C}\right)$ was poured in the beaker. The beakers were loaded in the system and temperature was set at $100^{\circ} \mathrm{C}$. The process was left to operate for 120 minutes and the temperature was increased to the 
recovery temperature, which was twice the initial boiling temperature. Rinsing was thus done twice in order to collect the remaining fat in the sample. Beakers were taken out and put Nitrogen $(\mathrm{g} / 100 \mathrm{~g})=14.01 \mathrm{x}$ Normality of HCL (0.1) x (TV-BV)SW (gm)x 100in a hot air oven. Thimble holders were removed from the beakers and the beakers were weighed. The amount of fat present in the sample was calculated using the following formula:

$$
\text { Weight of ether extract fat (B-A) }
$$

Fat $(\mathrm{g} / 100 \mathrm{~g})=\mathrm{X} 100$

$$
\text { Weight of sample (gm) }
$$

\section{Ash}

Ash was estimated by the method given by Jain and Mogra (2006). Five grams of moisture free sample was weighed in previously heated, cooled and weighed crucible. Sample was then completely charred on the hot plate, followed by heating in muffle furnace at $6000 \mathrm{C}$ for 5 hours. The crucible was cooled in desiccators and weighed. The process was repeated till constant weights were obtained and the ash was almost white or grayish in color. Ash content of samples was calculated using following formula:

$$
\text { Ash }(\mathrm{g} / 100 \mathrm{~g})=\frac{\text { Weight of ash }(\mathrm{g})}{\mathrm{X} 100}
$$

\section{Crude fibre}

Fibre is an insoluble vegetable matter indigestible by proteolytic and diastatic enzymes and cannot be utilized except by microbial fermentation. It is usually composed of cellulose, hemicelluloses and lignin. Crude fiber estimation was done as per the method given by 3 gram of moisture and fat free sample was placed in $500 \mathrm{ml}$ beaker and boiled with $200 \mathrm{ml}$ of 1.25 per cent sulphuric acid for thirty minutes. The volume was kept constant during boiling by adding hot distilled water. This was filtered through muslin cloth and the residue was washed with hot distilled water till free from acid. The residue was then transferred to same beaker and boiled for 30 minute with $200 \mathrm{ml}$ of 1.25 per cent sodium hydroxide solution. After boiling, mixture was filtered through muslin cloth and the residue was washed again with hot distilled water till free from alkali followed by washing with $50 \mathrm{ml}$ alcohol and ether. Then it was taken into a crucible (it was weighed before as W1) and residue was dried in an oven at 1300C for 2-3 hours, cooled and weighed (W2). Heat in muffle furnace at 6000C for 2-3 hours, then cool and weigh again (W3).

\section{Carbohydrate}

The carbohydrate content of the sample on dry weight basis was calculated by difference method (Jain and Mogra 2006) as given below:

Carbohydrate $(\mathrm{g} / 100 \mathrm{~g})=100-($ moisture + crude fibre + ash + protein + fat $)$

\section{Energy}

The energy value of sample was calculated using physiological fuel value i.e. 4, 9, 4 kcal per gram of protein, fat and carbohydrate respectively.

Energy $(\mathrm{kcal} / 100 \mathrm{~g})=[(\%$ protein $\mathrm{x} 4)+(\%$ carbohydrate x 4$)+(\%$ fat $\times 9)$ ]

\section{Mineral profile}

Mineral solutions of selected samples were prepared by wet ashing method compiled by Jain and Mogra (2006). The plant material was digested with a mixture of acids to form a clear white precipitate which was then dissolved in water and made up to a definite volume. An aliquot from this was used for determination of selected minerals. 


\section{Wet ashing}

One gram moisture free sample was taken in a digestion tube and $5 \mathrm{ml}$ of concentrated HNO3 was added to it and was left overnight. It was then heated slowly for 30 minutes and cooled. Five $\mathrm{ml}$ of perchloric acid $(70 \%)$ was added and heated over digestion block until the particles were completely digested and the solution became clear. After digestion, volume of digested matter was made up to 50 $\mathrm{ml}$ with double distilled water. Prepared mineral solution was stored in makeup bottles and mineral analysis was done by atomic absorption spectrophotometer (AAS4141)

\section{Anti- nutritional factors}

The nutritional quality and digestibility of plant nutrients is affected by the presence of anti nutritional factors. The presence of these anti-nutrients was analyzed in selected maize varieties.

\section{Total tannin estimation}

Total tannin content of the samples was estimated using the method of Atanassova and Christova (2009).Sample preparationThree $\mathrm{g}$ of the sample was mixed with $250 \mathrm{ml}$ distilled deionized water (dd $\mathrm{H} 2 \mathrm{O}$ ) and kept for 4 hours at room temperature and filtered in volumetric flask with filter paper. Tannin Essay-Twenty five $\mathrm{ml}$ infusion was measured into 1 litre conical flask then $25 \mathrm{ml}$ of indigo solution and $750 \mathrm{ml}$ distilled deionized water was added $0.1 \mathrm{~N}$ aqueous solution of potassium permanganate was used for titration till the blue color of solution changes to green color. Further few more drops were added until solution becomes golden yellow. Standard solution of indigo carmine was prepared as follows- six gm indigo carmine was dissolved in500 $\mathrm{ml}$ of distilled deionized water by heating, after cooling $50 \mathrm{ml}$ of 95 97\% sulphuric acid was added, the volume was raised to $1 \mathrm{~L}$ and then filtered. Indigo carmine was kept in brown bottle till the experiment completed. The blank test was carried out by titration of a mixture of $25 \mathrm{ml}$ Indigo carmine solution and $750 \mathrm{ml}$ of (dd $\mathrm{H} 2 \mathrm{O})$. All were analyzed in duplicates.

\section{Phytate}

Phytic acid content of the samples was estimated using the method compiled by Jain and Mogra (2006). One gram of moisture free finely ground sample was taken in a conical flask and added $50 \mathrm{ml} \mathrm{HCl}$. The mixture was shaken in a shaker for 3 hours and filtered. The clear filtrate thus obtained was reduced to $25 \mathrm{ml}$ over water bath. The filtrate was neutralized adding required amount of sodium hydroxide. Ten $\mathrm{ml}$ of 0.01 per cent ferric chloride was then added and the mixture heated over water bath for 15 minutes, cooled to room temperature and filtered again using a pre-weighed filter paper. The residue was washed with ethanol and then ether.

\section{Results and Discussion}

Chemical properties of buckwheat whole (BW), buckwheat groats (BG) and buckwheat husk $(\mathrm{BH})$ were analyzed and the results obtained on dry matter basis have been presented in following sections (Table 1-3).

\section{Proximate analysis}

Moisture, crude fat, ash, crude protein, crude fibre, carbohydrates and energy contents of $\mathrm{BW}, \mathrm{BG}$, and $\mathrm{BH}$ were estimated and results are depicted in Table 1.

The chemical analysis of buckwheat fractions for proximate composition revealed significant difference for moisture, fat, ash, protein, fibre and energy. Moisture content was significantly $((\mathrm{p} \leq 0.05)$ higher in $\mathrm{BW}$ $(8.56 \mathrm{~g} / 100 \mathrm{~g})$ followed by BG $(7.19 \mathrm{~g} / 100 \mathrm{~g})$ 
and $\mathrm{BH}(5.16 \mathrm{~g} / 100 \mathrm{~g})$. Highest amount of crude fat content was exhibited in BG $(2.68 \mathrm{~g} / 100 \mathrm{~g})$ followed by BW $(2.02 \mathrm{~g} / 100 \mathrm{~g})$ and $\mathrm{BH}(0.76 \mathrm{~g} / 100 \mathrm{~g})$. Ikeda and Yamashita (1994) reported that seeds of common buckwheat contain $1.5-3.7 \%$ total lipids. The highest concentration is in embryo and the lowest in the hull at $0.4-0.9 \%$. Groats or dehulled seeds of buckwheat contain 2.1$2.6 \%$ total lipids. Total ash was significantly higher in BW $(2.34 \mathrm{~g} / 100 \mathrm{~g})$ than BG $(2.04 \mathrm{~g} / 100 \mathrm{~g})$ and $\mathrm{BH} \quad(2.15 \mathrm{~g} / 100 \mathrm{~g})$. Bonafaccia et al., (2003) studied the composition and technological properties of the flour and bran from common and tartary buckwheat. The content of ash was found between the range of $1.82-4.08 \%$ among grain, brain and flour. Protein, the body building nutrient, was significantly higher in BG (14.88g/100g) than BW (11.34g/100g) and $\mathrm{BH}(9.91 \mathrm{~g} / 100 \mathrm{~g})$. Fornal (1999) reported that buckwheat flour contains from $8.5 \%$ to near $19 \%$ of proteins depending on the variety, pesticides used and fertilization that are likely to affect the total concentration of buckwheat proteins.

$\mathrm{BW}$ and $\mathrm{BH}$ showed significantly higher content of crude fibre $(9.35 \mathrm{~g} / 100 \mathrm{~g}$ and $10.74 \mathrm{~g} / 100 \mathrm{~g}$ ) respectively than in $\mathrm{BG}$ $(3.46 \mathrm{~g} / 100 \mathrm{~g})$. It was found that crude fibre was highest in bran $(10.74 \mathrm{~g} / 100 \mathrm{~g})$ and was lowest in BG (3.46 g/100g) as buckwheat groats was dehusked form of grain which affects the fibre content. Bonafaccia and Kreft (1994) found from $3.4 \%$ to $5.2 \%$ of total dietary fibre in buckwheat samples and products. Buckwheat may have, because of its fibre content may have an important role in prevention and treatment of hypercholestremia (He et al., 1995). It was observed that all three fractions of buckwheat exhibited almost similar values of carbohydrate content which ranged from $66.35 \mathrm{~g} / 100 \mathrm{~g}$ in BW to $71.25 \mathrm{~g} / 100 \mathrm{~g}$ in $\mathrm{BH}$.
In the whole grain of buckwheat, starch content varies from $59 \%$ to $70 \%$ of the dry mass, demonstrating fluctuations under variable climate and cultivation conditions. However the difference was found to be statistically non-significant. The energy values can also be seen to be varying possibly due to protein and carbohydrate content among $\mathrm{BW}, \mathrm{BG}$ and $\mathrm{BH}$. The values ranged from $329 \mathrm{kcal}$ in $\mathrm{BW}$ to $362 \mathrm{kcal}$ in $\mathrm{BG}$.

Kim et al., 2004) reported that buckwheat grains contain a variety of nutrients, the main compounds being protein, dietary fibre, lipids and carbohydrate. The total content of components depends on the variety or environmental factors (Barta et al., 2004). It can be concluded that BG is rich in protein, fat and content as compared to $\mathrm{BW}$ and $\mathrm{BH}$. Pomeranz and Robbins (1972) also suggested that BG is a good protein supplement.

\section{Mineral profile}

The major mineral contents for $\mathrm{BW}, \mathrm{BG}$ and $\mathrm{BH}$ are presented in Table 2. The significant difference was found between flours for calcium, Iron, and Zinc. In case of calcium, $\mathrm{BH}$ recorded higher value $149.66 \mathrm{ppm}$ than BW and BG (76.80 ppm and 38.13 ppm). Buckwheat is rich in potassium (k), magnesium (Mg) calcium (ca) and Sodium (Na) (Wei et al., 1995) and most of minerals are concentrated mainly in bran (Bonafacia et al., 2003).

Iron content was significantly higher in BW (106.83 ppm) followed by BG (80.61 ppm) and $\mathrm{BH}(47.10 \mathrm{ppm})$. Among three flours zinc content was found significantly higher in BG (23.83 ppm) than BW (20.50 ppm) and $\mathrm{BH}$ (14.83 ppm). Bonafacia et al., (2003) studied the content of $\mathrm{Se}, \mathrm{Zn}, \mathrm{Fe}, \mathrm{Co}, \mathrm{Ni}$ were analyzed in the flour and bran of common and tartary buckwheat. There is relatively small difference in the content of Iron, and 
chromium between flour and bran fractions. Though there was no significant difference observed for copper among BW, BG, and $\mathrm{BH}$ but the copper content of BW (14.1567 ppm) was found slightly higher than BG (10.9367 ppm) and BH (11.8333). Ikeda (1994) analyzed the content of zinc, copper and manganese in various samples of buckwheat. Generally the content of minerals in buckwheat grains and their morphological fractions (dry basis) reaches (6: $2-2.5 \%$ in whole grains, $1.8-2.0 \%$ in kernel, $2.2-3.5 \%$ in dehulled grains, about $0.9 \%$ in flour, and 3.4$4.2 \%$ in hulls (Li and Zhang, 2001).

Table.1 Proximate analysis of buckwheat whole (BW), buckwheat groats (BG) and buckwheat husk $(\mathrm{BH})$

\begin{tabular}{|c|c|c|c|c|c|c|c|c|c|c|c|c|c|c|c|}
\hline \multirow[t]{3}{*}{ S.N. } & \multirow[t]{3}{*}{ Treatment } & \multicolumn{14}{|c|}{ Nutrients g/100g } \\
\hline & & \multicolumn{2}{|c|}{ Moisture } & \multicolumn{2}{|c|}{ Fat } & \multicolumn{2}{|c|}{ Ash } & \multicolumn{2}{|c|}{ Protein } & \multicolumn{2}{|c|}{ Fibre } & \multicolumn{2}{|c|}{$\mathrm{CHO}$} & \multicolumn{2}{|c|}{$\begin{array}{l}\text { Energy } \\
\text { (Kcal) }\end{array}$} \\
\hline & & Mean & SD & Mean & SD & Mean & SD & Mean & SD & Mean & SD & Mean & SD & Mean & SD \\
\hline 1 & BW & 8.56 & 0.62 & 2.02 & 0.42 & 2.34 & 0.03 & 11.34 & 0.05 & 9.35 & 1.18 & 66.35 & 1.48 & 329 & 8.11 \\
\hline 2 & BG & 7.19 & 0.45 & 2.68 & 0.22 & 2.04 & 0.02 & 14.88 & 1.31 & 3.46 & 0.45 & 69.72 & 1.89 & 362 & 3.79 \\
\hline \multirow[t]{8}{*}{3} & $\mathrm{BH}$ & 5.16 & 0.62 & 0.76 & 0.34 & 2.15 & 0.04 & 9.91 & 0.91 & 10.74 & 1.00 & 71.25 & 2.50 & 331 & 4.99 \\
\hline & GM & 6.97 & 1.56 & 1.82 & 0.89 & 2.18 & 0.13 & 12.05 & 2.35 & 7.85 & 3.44 & 69.11 & 2.77 & 341 & 16.98 \\
\hline & $\mathrm{Se}$ & 0.32 & & 0.19 & & 0.02 & & 0.53 & & 0.54 & & 1.1586 & & 3.41 & \\
\hline & CD5\% & \multicolumn{2}{|c|}{$1.13^{*}$} & \multicolumn{2}{|c|}{$0.68 *$} & \multicolumn{2}{|c|}{$0.07 *$} & \multicolumn{2}{|c|}{$1.84^{*}$} & \multicolumn{2}{|c|}{$1.87 *$} & \multicolumn{2}{|c|}{$4.00 \mathrm{NS}$} & \multicolumn{2}{|c|}{$11.83^{*}$} \\
\hline & CD1\% & \multicolumn{2}{|c|}{$1.72^{*}$} & \multicolumn{2}{|c|}{$1.03 *$} & \multicolumn{2}{|c|}{$0.11 *$} & \multicolumn{2}{|c|}{$2.79 *$} & \multicolumn{2}{|c|}{$2.83^{*}$} & \multicolumn{2}{|c|}{$6.07 \mathrm{NS}$} & \multicolumn{2}{|c|}{$17.92 *$} \\
\hline & $\mathrm{CV}$ & \multicolumn{2}{|c|}{8.18} & \multicolumn{2}{|c|}{$\begin{array}{l}18.66 \\
2.85\end{array}$} & \multicolumn{2}{|c|}{1.76} & \multicolumn{2}{|c|}{7.67} & \multicolumn{2}{|c|}{11.94} & \multicolumn{2}{|c|}{2.90} & \multicolumn{2}{|c|}{1.74} \\
\hline & Treatment & \multirow{2}{*}{\multicolumn{2}{|c|}{$\begin{array}{l}8.81 \\
0.32\end{array}$}} & \multirow{2}{*}{\multicolumn{2}{|c|}{$\begin{array}{c}2.85 \\
0.116\end{array}$}} & \multicolumn{2}{|c|}{0.06} & 19. & & 44 & & 18. & & 104 & 3.26 \\
\hline & Error & & & & & $0 .($ & & 0.8 & & 0. & & 4.0 & & & 06 \\
\hline
\end{tabular}

$\mathrm{GM}=$ General Mean, $*$ Significant at $5 \%$ and $1 \%$ level of significance, NS $=$ Non-significant

Table.2 Mineral composition of buckwheat whole (BW), buckwheat groats (BG) and buckwheat husk $(\mathrm{BH})$

\begin{tabular}{|c|c|c|c|c|c|c|c|c|c|}
\hline \multirow[t]{2}{*}{ S.N. } & \multirow[t]{2}{*}{ Treatment } & \multicolumn{2}{|c|}{ Calcium (ppm) } & \multicolumn{2}{|c|}{ Iron (ppm) } & \multicolumn{2}{|c|}{ Zinc (ppm) } & \multicolumn{2}{|c|}{ Copper (ppm) } \\
\hline & & Mean & SD & Mean & SD & Mean & $\mathrm{SD}$ & Mean & $\mathrm{SD}$ \\
\hline $\mathbf{1}$ & BW & 76.80 & 0.57 & 106.83 & 2.68 & 20.50 & 1.58 & 14.15 & 3.55 \\
\hline 2 & $\mathrm{BG}$ & 38.13 & 0.97 & 80.61 & 5.00 & 23.83 & 1.28 & 10.93 & 0.58 \\
\hline 3 & $\mathrm{BH}$ & 149.66 & 6.12 & 77.10 & 2.73 & 14.83 & 1.17 & 11.83 & 1.06 \\
\hline & GM & 88.20 & 49.14 & 88.18 & 14.41 & 19.72 & 4.11 & 12.30 & 2.36 \\
\hline & $\mathrm{Se}$ & 2.07 & & 2.10 & & 0.78 & & 1.25 & \\
\hline & $\mathrm{CD} 5 \%$ & $7.18 *$ & & $7.27 *$ & & $2.71 *$ & & 4.3342 & NS \\
\hline & CD1\% & $10.88^{*}$ & & $11.01 *$ & & $4.11 *$ & & 6.5659 & $\mathrm{NS}$ \\
\hline & $\mathrm{CV}$ & 4.08 & & 4.13 & & 6.90 & & 17.62 & \\
\hline & Treatment & 9621.44 & & 791.87 & & 62.11 & & 8.28 & \\
\hline & Error & 12.93 & & 13.25 & & 1.85 & & 4.70 & \\
\hline
\end{tabular}

GM=General Mean, * significant at 5\% and $1 \%$ level of significance, NS $=$ Non-significant 
Table.3 Anti- nutritional analysis of buckwheat whole (BW), buckwheat groats (BG) and buckwheat huck $(\mathrm{BH})$

\begin{tabular}{|c|c|c|c|c|c|}
\hline \multirow{2}{*}{ S.N. } & \multirow{2}{*}{ Teatment } & \multicolumn{2}{|c|}{ Tannin\% } & \multicolumn{2}{c|}{ Phytic acid\% } \\
\cline { 3 - 6 } & & Mean & SD & Mean & SD \\
\hline $\mathbf{1}$ & BW & 4.16 & -0.00 & 18.36 & 1.90 \\
\hline $\mathbf{2}$ & BG & 4.16 & -0.00 & 6.23 & 2.40 \\
\hline $\mathbf{3}$ & BH & 5.54 & 0.00 & 18.30 & 3.71 \\
\hline & GM & 4.61 & 0.69 & 14.30 & 6.51 \\
\hline & Se & 0.00 & & 1.60 & \\
\hline & CD5\% & 0.00 & NS & 5.55 & \\
\hline & CD1\% & 0.00 & NS & 8.41 & \\
\hline & CV & 0.00 & & 19.45 & \\
\hline & Treatment & 1.91 & & $146.41 * *$ & \\
\hline & Error & 0 & & 7.73 & \\
\hline
\end{tabular}

$\mathrm{GM}=$ General Mean, *significant at $5 \%$ and $1 \%$ level of significance, $\mathrm{NS}=$ Non-significant

Plate.1

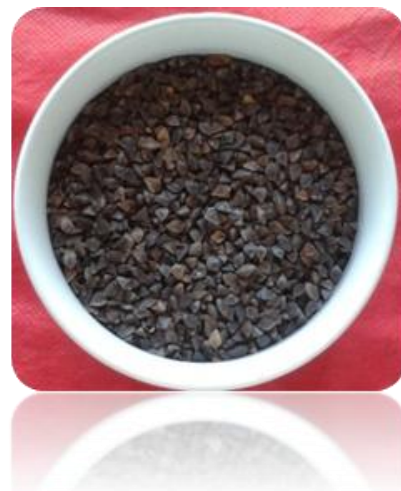

(Buckwheat-BW)



(Buckwheat Groats-BG) (Buckwheat Husk-BH)

\section{Anti-nutritional analysis}

The anti-nutritional factors viz tannin and phytic acid was analyzed in all flour fractions. The results obtained are presented in Table 3 and discussed below.

Tannin content was found to be highest in $\mathrm{BH}$ $(5.54 \%)$ than BW (4.16\%) and BG (4.16\%). No significant difference was found in the content of tannin. Sharma and Sahgal (1992) reported that buckwheat seeds contain from 0.5 to $4.5 \%$ tannin depending on the genotype and on ecological factors. The phytic acid content was significantly $((\mathrm{p} \leq 0.05)$ lower in BG $(6.233 \%)$ than BW $(18.36 \%)$ and $\mathrm{BH}$ (18.30\%). Skrabanjia et al., (2004) studied nutrient content in buckwheat milling fractions. A unique distribution was found in for phytate as correlation was significantly positive in husk, bran and semolina fractions, while correlation is significantly negative in flour fractions.

Depending on chemical analysis of buckwheat whole (BW), buckwheat groats 
(BG) and buckwheat husk (BH), the buckwheat groats considered nutritionally dense due to its better macro and micronutrient and low anti-nutritional content than BW and BH. Pomranz and Rabbins (1972) determined protein content and amino acid composition in buckwheat and found that groat is a good protein supplement. Phytic acid was found significantly negative in flour fraction than husk, bran and semolina fractions (Skrabanja et al.,)

\section{References}

Atanassova M. and Christova Bagdassarian V. 2009. Determination of tannin content by titrimetric method for comparison of different plant species. Journal of the University of Chemical Technology and Metallurgy.44 (4) 413-415.

Bonafaccia G., Marocchini M. and Kreft I. 2003.Composition and technologicalproperties of the flour and bran from common and tartary buckwheat.Food Chemistry.80: 9-15.

Bonafaccia G. and Kreft I. 1994. Technological and qualitative characteristics of food products made with buckwheat. Fagopyrum.14: 3542.

Barta J., Kalinova J., Moudry J. and Curn V. 2004.Effects of environmental factors on protein content and composition in buckwheat flour. Cereal Research Communications.32: 541-548.

Fornal L. 1999. Chemizmnasiongryki i kierunkispożywczegowykorzystania. Biuletyn Naukowy. 4: 7-17.

Friendrich M., Stuhlfelder C., Theurer C. 2000. Buckwheat- herbal drug through the ages. Zeitscrift-fur Phytotherapie, 21: 106-114

He J., Klag M. J., Whelton P. K., Mo J. P., Chen J. Y., Qian M. C., Mo P. S. and He G. Q. 1995. Oats and buckwheat intakes and cardiovascular disease risk factors in an ethnic minority of China. American Journal of Clinical Nutrition.61: 366-732.

Ikeda S. and Yamashita Y. 1994.Buckwheat as a dietary source of zinc, copper and manganese. Fagopyrum. 14: 29-34.

Javornik B. \& Kreft, I. (1984), Characterization of buckwheat proteins, Fagopyrum4:30 38.

Jain S. and Mogra R. (2006), Analysis of food components: Practical Mannual, Department of Food and Nutrition, College of Home Science, Maharana Pratap University of Agriculture and Technology, Udaipur, Rajasthan, India

Krotov A.S. 1963. Buckwheat, Izdatel' stvosel Skonozjstvermij Literatury, Moscow (In Russian).

Kim S.L., Kim S.K. and Park C.H. 2004. Introduction and nutritional evaluation of buckwheat sprouts as a new vegetable. Food Research International. 37:319-327.

Lipkin M., Reddy B., Newmark H. \&Lamprecht S.A. (1999), Dietary fractors in human colorectal cancer, Annual. Review of Nutrition.19:545586.

Li S. and Zhang Q.H. 2001. Advances in the development of functional foods from buckwheat. Critical Reviews in Food Science and Nutrition.41: 451-464.

NIN. 1983. A manual of laboratory techniques, Raghuramlu, N, Nair, K. Mand Kalyanasundram, S. Eds. National Institute of Nutrition, ICMR, Hyderabad.

Pomeranz Y. and Robbins G.S. 1972.Amino acid composition of buckwheat. Journal of Agriculture Food Chernistry.20: 270-274.

Pomeranz Y. (1983), Buckwheat: structure, composition and utilization, Critical Review of Food Chemistry.19 : 213258. 
Santos K.F.R., Oliveira T.T., Nagem T.J., Pinto A.S. and Oliveira M.G.A. (1999),

Hypolipidaemic effects of narigenin, rutin, nicotinic acid and their associations, Pharma. Res. 40: 493-496.

Steadman K.J., Burgoon M.S., Lewis B.A., Edwardson S.E. and Obendorf R.L. 2001. Buckwheat seed milling fraction: description, macronutrient composition and dietary fibre. Journal of Cereal Science.33: 271-278.

Skrabanja V., Kreft I., Golob T., Modic M., Ikeda, S., Ikeda K., Kreft S., Bonafaccia G., Knapp M. and Kosmelj K. 2004. Nutrient Content in Buckwheat Milling Fractions. In Cereal Chemistry.172-176.

Wei Y., Zhang G.Q. and Li Z.X. 1995. Study on nutritive and physico-chemical properties of buckwheat flour. Nahrung.39: 48-54.

\section{How to cite this article:}

Mani Mishra and Shashi Jain. 2019. A Comparative Study on Nutritional Profile and Antinutrients of Buckwheat Fractions (Fagopyrum esculentum). Int.J.Curr.Microbiol.App.Sci. 8(03): 561-570. doi: https://doi.org/10.20546/ijcmas.2019.803.068 